J. Clin. Chem. Clin. Biochem.

Vol. 17,1979 , pp. $331-336$

\title{
Reduction of Sample Volume in the SMA 12/60
}

\author{
By S. T. IJpma, C. J. Jongkind and B. Leijnse \\ Department of Clinical Chemistry, University Hospital Rotterdam-Dijkzigt and Department of Chemical Pathology, \\ Erasmus University, Rotterdam, The Netherlands
}

(Received September 22, 1978)

Summary: A modification of the flow system of the Technicon SMA 12/60 Continuous Flow Analyzer is described. This modification results in a $60 \%$ reduction of the sample volume. The sample size required for the analysis of twelve constituents in serum is thereby reduced to only $0.7 \mathrm{ml}$. This modification is simple and does not require complex hardware. The reduction in sample size also leads to a considerable cost reduction (25\%).

\section{Verringertes Probenvolumen für den SMA 12/60}

Zusammenfassung: Eine Modifikation des Fließschemas für die Verfahren des Technicon SMA 12/60 Continuous Flow Analyzer wird beschrieben. Das Probenvolumen wird um 60\% verringert; es beträgt für die Analyse von 12 Serumbestandteilen nur noch 0,7 ml. Die Modifikation ist einfach und erfordert keine komplexe „hardware“. Die beschriebene Umstellung reduziert die Kosten um ein Viertel.

\section{Introduction}

In the mid-1960's Technicon introduced the SMA 12/60, a continuous flow system that analyses twelve constituents in serum per minute.

In our laboratory, about $90 \%$ of the quantitative serum analyses are performed on an SMA 12/60. The required sample volume depends on the constituents to be analyzed. In general, an analysis on an SMA $12 / 60$ requires about $2 \mathrm{ml}$ of serum.

In the last few years, it is possible to detect a trend towards the use of ever smaller sample volumes with the large analytical systems. We therefore studied the possibility of reducing the sample volume in the SMA 12/60.

During this study, in July 1976, Shihabi et al. (1) published a modification of the SMA $6 / 60$ enabling a reduction of sample volume from 550 to $90 \mu$ l. Normally, only about $10 \%$ of the small molecules are dialyzed in the continuous flow system. The rest is pulled away to the drain. Shihabi et al. modified the manifold of the SMA $6 / 60$ by placing the dialyzers serially, in order to use the sample more effectively.

The work of Shihabi et al. involves 6 chemical analyses, namely carbon dioxide content, șodium, potassium, chloride, glucose and urea nitrogen. Only four of these coincide with the analyses performed on our SMA 12/60.
In order to obtain a considerable reduction in sample size in our SMA 12/60, serial dialysis in four channels is not enough. In addition, in larger systems, like the SMA $12 / 60$, depending on the choice of tests, a number of methodologies are used without dialysis. Under these circumstances, one can try to diminish the sample volume either by aspirating less, or by using a more dilute sample.

The technique of serial dialysis is very simple, and no complicated hardware is needed. We therefore decided to try to diminish our sample volume on the SMA 12/60 partly by using serial dialysis (incorporating more channels of analysis); and partly by adaptation of the "resample-line", which includes three analytical methods (and two blanks) which do not use a dialyzer. This resulted in a modification of the flow system of the chemistries of our SMA 12/60 (as is outlined in fig. 1).

\section{Materials and Methods}

The SMA 12/60 used was a standard model. The instrument includes the following channels: sodium, potassium, chloride, total protein, albumin, calcium, inorganic phosphorus, uric acid, urea nitrogen, total bilirubin, creatinine and alkaline phosphatase (EC 3.1.3.1). The analytical methods used are described by Technicon Corp. (SMA $12 / 60$ manual). 

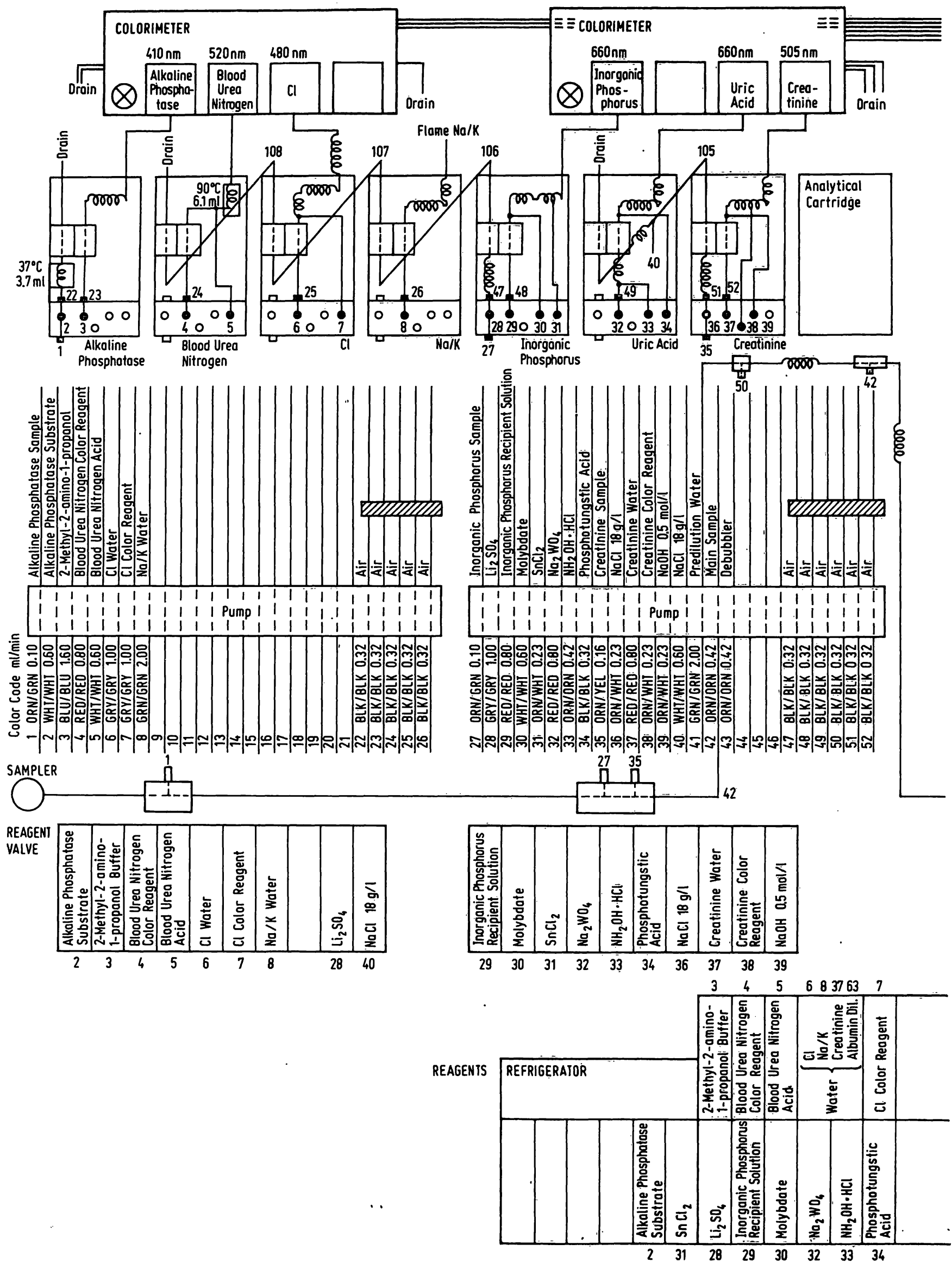

Fig. 1. Modified flow system for the chemistries of the SMA $12 / 60$. 


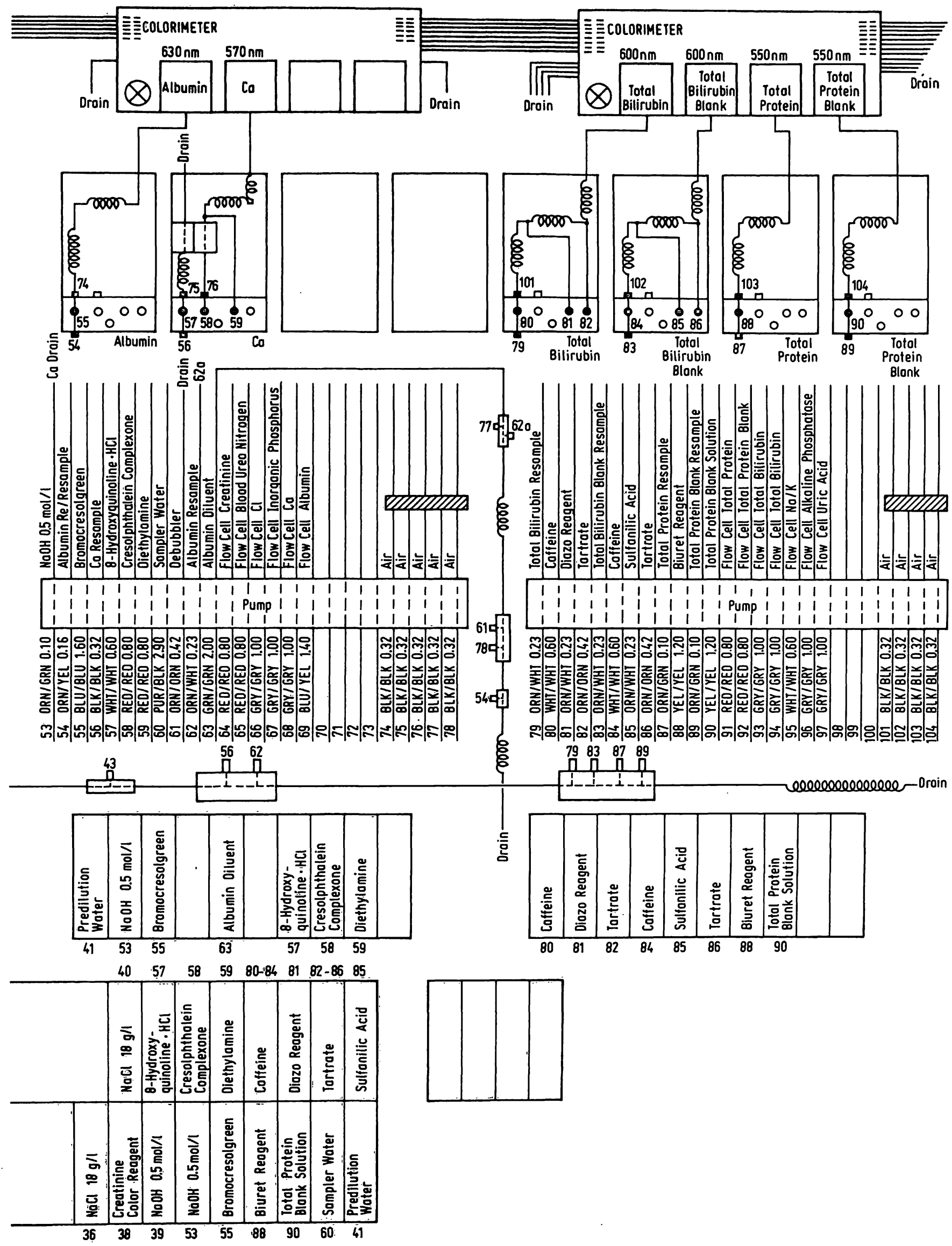


Only the manifold of the creatinine channel was modified in cooperation with Technicon Corporation (The Netherlands). Instead of a 12 inch dialyzer we use a 24 inch dialyzer. In this way, the sample volume needed for the creatinine analysis was reduced to $0.23 \mathrm{ml} / \mathrm{min}$ (standard $0.42 \mathrm{ml} / \mathrm{min}$ ). As a consequence we had to increase the consumption of sodium chloride $18 \mathrm{~g} / 1$ from 0.42 to $0.60 \mathrm{ml} / \mathrm{min}$.

The SMA 12/60 uses Terhnicon reagents and is calibrated with Technicon lyophilized reference serum, for which set point values are established in our laboratory.

Like Shihabi et al. we occasionally saw (in the modified SMA $12 / 60$ ) a precipitate in the urea nitrogen dialyzer. It appeared that this depends on the batch of blood urea nitrogen colour reagent used. We now prepare this reagent ourselves employing pure chemicals.

\section{Results}

Our revised manifold of the SMA $12 / 60$ uses $\mathrm{Li}_{2} \mathrm{SO}_{4}$ in $0.125 \mathrm{~mol} / \mathrm{H} \mathrm{H}_{2} \mathrm{SO}_{4}$, as a sample diluent for the sodium, potassium and urea nitrogen analysis. This is also the acid reagent for the chloride and the inorganic phosphorus analysis. In this way we could combine, via the technique of serial dialysis, the analysis of inorganic phosphorus, sodium and potassium, chloride and urea nitrogen (see fig. 1). These five constituents together require a sample volume of only $0.10 \mathrm{ml} / \mathrm{min}$.

In trying to join the uric acid analysis, a precipitate appeared in the dialyzer. This could be prevented by combining the uric acid with the creatinine channel (together a required sample volume of $0.16 \mathrm{ml} / \mathrm{min}$ ).

Furthermore, the volume pumped by the "resampleline" (albumin, calcium, total bilirubin and total protein) was reduced markedly $(0.42 \mathrm{ml} / \mathrm{min}$ instead of $0.80 \mathrm{ml} /$ min). Finally even in the alkaline phosphatase analysis, the sample size was reduced from 0.32 to $0.10 \mathrm{ml} / \mathrm{min}$. As we wanted to maintain the same incubation time the coil in the heating bath at $37^{\circ} \mathrm{C}$ was reduced from $7.7 \mathrm{ml}$ to $3.7 \mathrm{ml}$, changing the incubation time from 5.1 $\mathrm{min}$ to $5.3 \mathrm{~min}$.

The overall result is a volume reduction from 1.91 to $0.78 \mathrm{ml} / \mathrm{min}$. The actual sample consumption is $0.68 \mathrm{ml}$, because the SMA aspirates the sample for $52 \mathrm{~s}$ during each cycle of one minute.

Nów four reagents are superfluous, namely $\mathrm{NaCl} 9 \mathrm{~g} / 1$, acid for chloride, water for blood urea nitrogen and $\mathrm{H}_{2} \mathrm{SO}_{4}$ for inorganic phosphorus. The reagent consumption is also markedly reduced, namely $50 \%$ with respect to the alkaline phosphatase substrate, and the $\mathrm{Li}_{2} \mathrm{SO}_{4}$ for the $\mathrm{Na} / \mathrm{K}$ analysis. Consumption of water for chloride and chloride colour reagent was reduced by $38 \%$. On the other hand the consumption of $\mathrm{NaCl}$ $18 \mathrm{~g} / \mathrm{l}$ increases by $38 \%$. At the same time in this modification eleven pump tubes were deleted and a smaller type of sample cup can be used; this further reduces the overall costs. All changes (with respect to the standard SMA 12/60) are schematically outlined in table 1.

\section{Reliability}

The accuracy of the modified SMA 12/60 appeared to be no different from that of the standard analyzer, as indicated by the correlation data (see tab. 3).

The same holds true for the linearity and for interaction between samples.

Tab. 1. The essential changes of the chemical part of the SMA $12 / 60$, as compared with the original version.

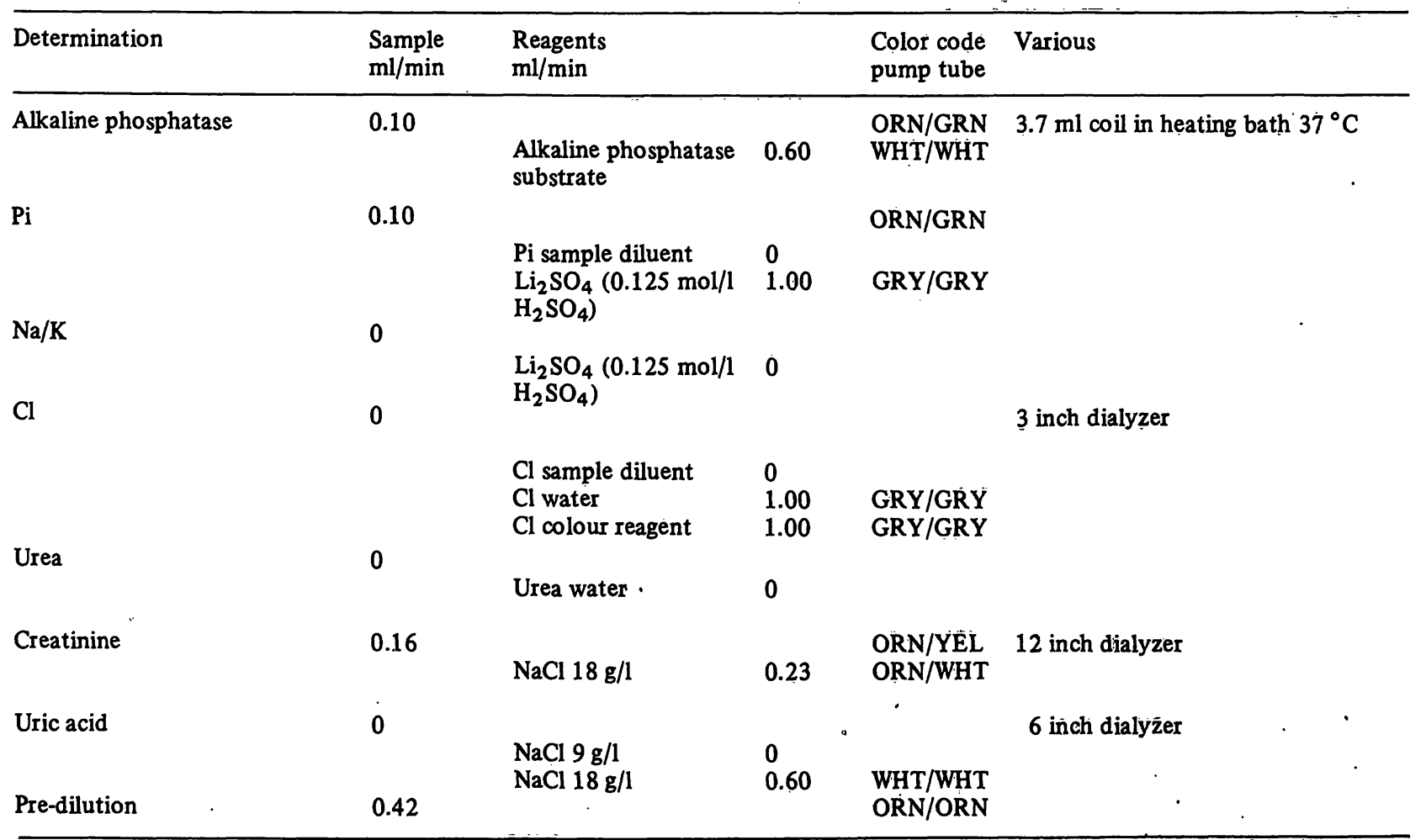


Precision of SMA-analysis can be checked with the aid of a control serum. In this case we used a commercially available serum (Autonorm Bovine, Nyegaard $\mathrm{Cy}$ ), which in daily routine on the SMA $12 / 60$ is analyzed once per 20 patient samples. The reproducibility is determined by choosing at random a single daily result of the control serum during each of 20 successive days. The mean, standard deviation (SD) and coefficient of variation (CV) of these day-to-day data are given in table 2 .

Table 3 lists data for repeatibility. The same period of 20 successive days is used to calculate the daily withinday data of analyses of control serum samples (on average each day 19 results). The range of the mean and the coefficient of variation and their means over those 20 days have been outlined.

For comparison table 3 shows the within-run precision for our modified SMA 12/60 and for a standard analyzer. The within-run precision is determined by analyzing a control serum 20 times in succession. The within-run data for the standard SMA 12/60 have been published by Technicon in their description of analytical methods. The standard and modified flow systems of the chemistries of the SMA 12/60 were correlated by analyzing 53 patient sera by each method at the same time. The results of this correlation are summarized in table 4 by means of the parameters ( $a$ and $b$ ) of the regression equation $y=a x+b$, and the correlation factor $r$ (method of the least squares). $y$ represents the SMA $12 / 60$ with the original version and $x$ is the modified one.

\section{Discussion}

In a standard SMA $12 / 60$ a sodium and potassium analysis requires $0.23 \mathrm{ml}$ of serum. The chloride and urea nitrogen analysis uses a prediluted sample, so that a modification, according to Shihabi et al., of these four analytical methods alone yields a reduction in sample size of only about $16 \%$. Of the other five channels, using a dialyzer, another three analyses (inorganic phosphorus, uric acid and creatinine) were modified, by using the technique of serial dialysis.

In this way two groups of analytical methods (with serial dialysis) could be formed, consisting of 5 and 2 methods. Even the main sample size of each group was reduced and, of course, reagent consumption was adapted.

Methods using a prediluted sample could be changed by reducing sample size for the "resample-line" and thus in

Tab. 2. Day-to-day precision of the modified SMA $12 / 60$ with a control serum $(n=20)$.

\begin{tabular}{|c|c|c|c|c|c|c|c|c|c|c|c|c|}
\hline & $\mathrm{Na}^{1}$ & $\mathrm{~K}^{1}$ & $\mathrm{Cl}^{1}$ & $\begin{array}{l}\text { Total } \\
\text { protein }\end{array}$ & Albumin & ${ }^{2} \mathrm{Ca}^{1}$ & $P_{i}^{1}$ & Urea $^{1}$ & $\begin{array}{l}\text { Uric } \\
\text { acid }^{1}\end{array}$ & $\begin{array}{l}\text { Crea- } \\
\text { tinine }^{3}\end{array}$ & $\begin{array}{l}\text { Bili- } \\
\text { rubin }{ }^{3}\end{array}$ & $\begin{array}{l}\text { Alkaline } \\
\text { Phospha- } \\
\text { tase }\end{array}$ \\
\hline $\begin{array}{l}\overline{\mathrm{x}} \\
\mathrm{SD} \\
\mathrm{CV}(\%)\end{array}$ & $\begin{array}{l}139 \\
1.2 \\
0.8\end{array}$ & $\begin{array}{l}4.33 \\
0.060 \\
1.4\end{array}$ & $\begin{array}{l}105 \\
1.9 \\
1.8\end{array}$ & $\begin{array}{l}74.9 \\
1.35 \\
1.8\end{array}$ & $\begin{array}{l}39.5 \\
0.79 \\
2.0\end{array}$ & $\begin{array}{l}2.26 \\
0.043 \\
1.9\end{array}$ & $\begin{array}{l}1.71 \\
0.033 \\
1.9\end{array}$ & $\begin{array}{l}12.3 \\
0.19 \\
1.5\end{array}$ & $\begin{array}{l}0.45 \\
0.012 \\
2.7\end{array}$ & $\begin{array}{l}170 \\
4.1 \\
2.4\end{array}$ & $\begin{array}{l}32 \\
1.1 \\
3.5\end{array}$ & $\begin{array}{l}94 \\
3.5 \\
3.7\end{array}$ \\
\hline
\end{tabular}

\begin{tabular}{|c|c|c|c|c|c|c|c|c|}
\hline \multirow[t]{2}{*}{ Constituent } & \multicolumn{4}{|c|}{ SMA $12 / 60$ Within-run precision } & \multicolumn{4}{|c|}{ SMA $12 / 60$ Within-day precision } \\
\hline & $\frac{\text { Modifiéd }}{\bar{x}}$ & CV (\%) & $\frac{\text { Standard }}{\mathbf{x}}$ & CV $(\%)$ & $\begin{array}{l}\text { Modified } \\
\text { range }\end{array}$ & $\begin{array}{l}\bar{x} \\
\text { mean }\end{array}$ & range & $\begin{array}{c}\mathrm{CV}(\%) \\
\text { mean }\end{array}$ \\
\hline $\begin{array}{l}\text { Sodium (mmol/1) } \\
\text { Potassium (mmol/l) } \\
\text { Chloride (mmol/l) } \\
\text { Total protein (g/l) } \\
\text { Albumin }(\mathrm{g} / \mathrm{l}) \\
\text { Calcium (mmol/1) } \\
\text { Inorganic phosphorus } \\
\text { (mmol/l) }\end{array}$ & $\begin{array}{l}138 \\
4.31 \\
104 \\
72.2 \\
39.1 \\
2.28 \\
1.70\end{array}$ & $\begin{array}{l}0.4 \\
0.8 \\
1.0 \\
1.6 \\
0.9 \\
0.8 \\
0.8\end{array}$ & $\begin{array}{l}141 \\
3.61 \\
102 \\
76.4 \\
41.7 \\
2.47 \\
1.67\end{array}$ & $\begin{array}{l}0.6 \\
0.9 \\
0.9 \\
0.8 \\
1.0 \\
1.4 \\
1.4\end{array}$ & $\begin{array}{l}138-139 \\
4.28-4.35 \\
104-106 \\
73.4-76.2 \\
39.0-39.8 \\
2.23-2.30 \\
1.68-1.75\end{array}$ & $\begin{array}{l}139 \\
4.31 \\
105 \\
74.6 \\
39.5 \\
2.26 \\
1.71\end{array}$ & $\begin{array}{l}0.5-1.2 \\
0.8-1.7 \\
1.0-2.3 \\
1.1-2.1 \\
1.3-2.3 \\
1.3-2.7 \\
1.0-2.4\end{array}$ & $\begin{array}{l}0.8 \\
1.2 \\
1.5 \\
1.6 \\
1.9 \\
1.9 \\
1.8\end{array}$ \\
\hline $\begin{array}{l}\text { Uric acid (mmol/1) } \\
\text { Urea nitrogen (mmol/1) } \\
\text { Creatinine ( } \mu \text { mol/1) } \\
\text { Total bilirubin ( } \mu \mathrm{mol} / \mathrm{l}) \\
\text { Alkaline phosphatase } \\
\text { (U/1) }\end{array}$ & $\begin{array}{l}0.45 \\
12.5 \\
169 \\
35 \\
94\end{array}$ & $\begin{array}{l}0.8 \\
0.7 \\
2.2 \\
1.8 \\
0.9\end{array}$ & $\begin{array}{l}0.42 \\
11.5 \\
449 \\
34 \\
102\end{array}$ & $\begin{array}{l}1.7 \\
2.4 \\
1.9 \\
1.2 \\
0.6\end{array}$ & $\begin{array}{l}0.44-0.46 \\
12.2-12.6 \\
169-183 \\
32-34 \\
90-96\end{array}$ & $\begin{array}{l}0.45 \\
12.3 \\
172 \\
33 \\
94\end{array}$ & $\begin{array}{l}1.7-4.2 \\
1.0-3.2 \\
2.3-7.5 \\
2.5-7.2 \\
2.0-4.7\end{array}$ & $\begin{array}{l}2.9 \\
1.5 \\
3.6 \\
4.5 \\
3.2\end{array}$ \\
\hline
\end{tabular}


Tab. 4. Parameters of the regression equation $y=a x+b$, with correlation factor $r$, as measured on the SMA 12/60. y represents the original and $x$ the modified version of the SMA $12 / 60$.

${ }^{1}(\mathrm{mmol} / \mathrm{l}) ;{ }^{2}(\mathrm{~g} / \mathrm{l}) ;{ }^{3}(\mu \mathrm{mol} / \mathrm{l}) ;{ }^{4}(\mathrm{U} / \mathrm{l})$.

\begin{tabular}{|c|c|c|c|c|c|c|}
\hline & $\mathrm{Na}^{1}$ & $\mathrm{~K}^{1}$ & $\mathrm{Cl}^{1}$ & $\begin{array}{l}\text { Total } \\
\text { protein }\end{array}$ & Albumin $^{2}$ & $\mathrm{Ca}^{1}$ \\
\hline \multirow[t]{2}{*}{$\begin{array}{l}\mathbf{a} \\
\mathrm{b} \\
\mathbf{r}\end{array}$} & $\begin{array}{l}1.02 \\
-2 \\
0.973\end{array}$ & $\begin{array}{l}1.02 \\
-0.13 \\
0.999\end{array}$ & $\begin{array}{l}1.05 \\
-4 \\
0.976\end{array}$ & $\begin{array}{l}1.05 \\
-3.5 \\
0.989\end{array}$ & $\begin{array}{l}0.97 \\
0.8 \\
0.992\end{array}$ & $\begin{array}{l}0.94 \\
0.14 \\
0.990\end{array}$ \\
\hline & $P_{i}^{1}$ & Urea $^{1}$ & $\begin{array}{l}\text { Uric } \\
\text { acid }^{1}\end{array}$ & Creatinine $^{3}$ & Bilirubin $^{3}$ & $\begin{array}{l}\text { Alkaline } \\
\text { Phosphatase }\end{array}$ \\
\hline $\begin{array}{l}a \\
b \\
\text { r }\end{array}$ & $\begin{array}{l}1.02 \\
-0.02 \\
0.998\end{array}$ & $\begin{array}{l}1.01 \\
0 \\
1.00\end{array}$ & $\begin{array}{l}1.02 \\
0 \\
0.999\end{array}$ & $\begin{array}{l}1.02 \\
-6 \\
0.998\end{array}$ & $\begin{array}{l}0.91 \\
0 \\
0.997\end{array}$ & $\begin{array}{l}0.97 \\
-1 \\
0.999\end{array}$ \\
\hline
\end{tabular}

using a more diluted sample (5.8 times instead of 3.5 times diluted). By these modifications the sample size is reduced by $60 \%$, so that only $0.7 \mathrm{ml}$ serum is required for the analysis of twelve constituents.

In comparison, the Technicon SMAC uses about $0.6 \mathrm{ml}$ (for 20 components). Looking at the precision data for the SMAC, published by Schwartz et al. (2) one notices that our data are in good agreement.

Furthermore, precision comparisons between our modified and the standard SMA 12/60 also show good agreement.

The modification of the chemical console is very simple and can be done in minimal time. By changing the sequence of the analytical cartridges it is necessary to rearrange the connections with the reagents and colorimeters (inclusive the electric connections on the matrix board). Finally the whole system has to be phased again. The entire modification, as described here, can be implemented by two persons in a day.

By this reduction of the sample size we achieved a $25 \%$ reduction in the overall costs of reagents, calibration and control sera. On our basic production of $1976 / 1977$ this means a saving of about US $\$ 9000$ a year.

This system has already been functioning to our satisfaction for over a year with good reliability.

\section{Acknowledgements}

We thank Dr. B. G. Blijenberg and Drs. G. J. M. Boerma for their helpful comments on the manuscript.

\section{References}

1. Shihabi, Z. K. \& Turner, J. C. (1976), Clin. Chem. 22, 11071109.

2. Schwartz, M. K., Bethune, V. G., Fleisher, M., Pennacchia, G., Menendez-Botet, C. J. \& Lehman, D. (1974), Clin. Chem. 20, 1062-1070.

\section{Ir. S. T. IJpma}

Department of Clinical Chemistry

University Hospital Rotterdam-Dijkzigt

Dr. Molewaterplein 40

Rotterdam

The Netherlands 